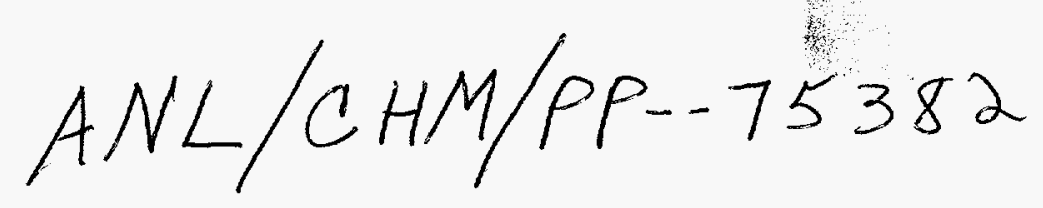

\title{
An Improved and facile method for the synthesis of 1,1-bis(4- hydroxyphenyl)-2-phenylethylene and its derivatives
}

Babak Shafii ${ }^{\star} \neq$, Robert W. Atcher and Eugene R. DeSombreł

Nuclear Medicine Research Group, Building 211, Argonne National Laboratory, 9700 S. Cass Ave., Argonne, IL 60439, and Ben May Institute, The University of Chicago, 5841 South Maryland Ave., Chicago, IL 60637, U.S.A.

* To whom correspondence should be addressed: Nuclear Medicine Research Group, Building 211, Argonne National Laboratory, 9700 S. Cass Ave., Argonne, IL 60439. Telephone (708) 972-6825; FAX (708) 972-5286.

a Argonne National Laboratory

¥ University of Chicago

\section{DISCLAIMER}

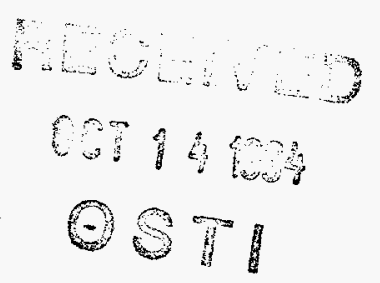

This report was prepared as an account of work sponsored by an agency of the United States Government. Neither the United States Government nor any agency thereof, nor any of their employees, makes any warranty, express or implied, or assumes any legal liability or responsibility for the accuracy, completeness, or usefulness of any information, apparatus, product, or bility for the accuracy, completeness, or usefulness of any information, apparatus, prods. ence herein to any specific commercial product, process, or service by trade name, trademark, manufacturer, or otherwise does not necessarily constitute or imply its endorsement, recommendation, or favoring by the United States Government or any agency thereof. The views and opinions of authors expressed berein do not necessarily state or reflect those of the United States Government or any agency thereof. 


\section{DISCLAIMER}

Portions of this document may be illegible in electronic image products. Images are produced from the best available original document. 


\section{ABSTRACT}

The synthesis of 1,1-bis(4-hydroxyphenyl)-2-phenylethylene, which is of biological interest, has been reported by several authors in the past. In this article an improved method is introduced. Different (and commercially available) starting materials are adopted. Also a protective group which is easily attached and removed is used. This procedure provides milder reaction conditions and better yields while the number of steps involved in the synthesis of the compound are reduced. Furthermore the reactions are clean and formation of byproducts which lead to poorer yields are avoided.

\section{INTRODUCTION}

Triphenylethylenes are of medical interest due to their estrogen receptor binding properties (1). This category of compounds labeled with radioactive halogens have shown promise in the diagnosis and treatment of certain types of cancer (2).

The synthesis of triphenylethylenes in general is easily accomplished through the condensation of benzophenones and benzylgrignards (3). Furthermore, tetrahydropyranyl (THP) group offers protection for the hydroxy groups in the basic medium, while placement and removal of this moiety can be easily accomplished under mild conditions (4).

\section{Results and Discussion}

The procedure reported here (scheme I) has the following advantages over the published procedures $(2,5)$ for the synthesis of III:

It is clean i.e. it is free of side products. The side products which rise form metallation of the benzylic hydrogens in the procedure involving condensation of a ketones and arylgrignards are a nuisance (for example see Ref 6). Removal of these side products are accomplished with difficulty (if at all) and at the expense of yield, time and resources. Secondly, the harsh conditions i.e. high temperatures and pressures and strong acidic or basic conditions which are employed in the published methods $(2,5)$ 
for removing the protecting alkoxy groups are avoided. Third, the commercial availability of the starting material exploited in this procedure reduces the number of the steps involved. Finally the yield in this method is higher than the methods already reported $(2,5)$.

However, the procedure which leads to the formation of the organometallic derivatives of BHPE (i.e. III) (2) has not been improved substantially (scheme II). Noteworthy is the use of diethylether instead of THF in the lithium-halogen exchange step (scheme III). The formation of the lithium derivative $\mathrm{VI}$ is best indicated by the clear orange solution. This is in contrast to the vinylbromide precursor $V$ which is sparingly soluble in the solvent medium. If THF is used instead of ether as the solvent at the lithium-halogen exchange step, a dark red transparent solution results which does not react with the added tributyltinchloride. This is presumably due to an electron transfer from $n$-butyllithium to $V$ assisted by THF.

The tin compound reported here (i.e. VII) is used for radioiodination. Following the radiolabeling step, the compound $1^{*}$-BHPE is purified via HPLC (2) and is ultimately of interest and is used for treatment in cancer research. Therefore, the synthesis of the cold iodo derivative (i.e. IX), which we report here, was also essential for studying the chemical toxicity of the compound.

\section{Experimental Procedures}

The ${ }^{1} \mathrm{H}$ NMR spectra were recorded by Argonne National Laboratory's Nicolet NTC 200 and Bruker AM-300 spectrometers. The mass spectrum was recorded using Argonne's Kratos MS 50 high resolution triple focus ion mass spectrometer. Melting points were measured by electrothermal melting point apparatus and are uncorrected. Elemental analysis were performed by Atlantic Microlab, Inc.

All the glassware were treated in $\mathrm{KOH}$-Ethanol bath for $10 \mathrm{~h}$ before use: All reactions involving organometallic compounds were carried under a dry and oxygen free atmosphere of pure argon. The chemicals were obtained from Aldrich chemical company (unless otherwise indicated) and were used without purification except for 
3,4-dihydropyran which was distilled from lithiumaluminumhydride (LAH) and was stored under argon for later use. All solvents used in the reactions involving organometallic compounds were freed of moisture and oxygen by refluxing over and distilling from appropriate material under an atmosphere of dry and oxygen free argon gas and were used fresh. The solvents were transferred to the reaction apparatus using syringe and needle.

Tetrahydrofuran (THF) and diethylether were refluxed over $\mathrm{LiAlH}_{4}(\mathrm{LAH})$ for at least $2 \mathrm{~h}$ before distillation.

\section{Synthesis of 4, 4'-bis[(2-tetrahydropyranyl)oxy]-benzophenone 1}

In a $500 \mathrm{~mL}$ round bottomed flask (r.b.f.) equipped with a magnetic stirrer was placed $15.0 \mathrm{~g}$ (70 mmoles) of 4,4'-dihydroxybenzophenone (Lancaster Synthesis) and $1 \mathrm{~g}$ (4 mmoles) of pyridinium-p-toluenesulfonate (PPTS). Then $\mathrm{CH}_{2} \mathrm{Cl}_{2}$ (200 mL) and $20 \mathrm{~mL}$ (220 mmoles) of 3,4-dihydropyran were added. The flask was then surmounted by a reflux condenser and topped by a drying tube. The slurry was stirred at R.T. for $2 \mathrm{~h}$ before a clear orange colored solution resulted. This was then refluxed for $0.5 \mathrm{~h}$. The flask contents were then transferred to a separatory funnel and washed with water $(200 \mathrm{~mL})$ followed by brine (i.e. Saturated salt-water solution, $200 \mathrm{~mL}$ ). The organic phase was then separated, dried $\left(\mathrm{Na}_{2} \mathrm{SO}_{4}\right)$ and filtered to give a clear orange solution. TLC of this orange solution vs. the starting material (silicagel, $2: 1$, hexanes: ethylacetate) showed one spot $R_{f}=0.45$, while starting material had $R_{f}=0.12$. Rotary evaporation gave a light orange oil weighing $29 \mathrm{~g}$. This oil was extracted with hot hexanes $(4 \times 100 \mathrm{~mL})$ and the combined extracts produced $21.4 \mathrm{~g}$ of white fluffy crystals of I (not reported in the literature), $80 \%$ yield, $\mathrm{mp} 105-107^{\circ} \mathrm{C}$.

1H NMR $\left(\mathrm{CDCl}_{3}\right): \delta$ 7.9-7.7 (d, 4), 7.3-7.0 (d, 4), $5.55(\mathrm{t}, 2), 3.5-4.0(\mathrm{~m}, 4), 2.1-1.5(\mathrm{~m}$, 12).

Elemental analysis: Calc'd. $\mathrm{C}=72.25 \%, \mathrm{H}=6.80 \%$ $\mathrm{C}_{23} \mathrm{H}_{26} \mathrm{O}_{5} \quad$ Found $\mathrm{C}=72.08 \%, \mathrm{H}=6.90 \%$ 
Synthesis of 1, 1-bis[(4-tetrahyropyranyloxy)phenyl]-2-phenylethanol II

In a set up consisting of a $250 \mathrm{~mL}$ r.b.f. which was surmounted by a condenser and topped with a gas inlet adapter was placed $27.5 \mathrm{~g}$ (72 mmoles) of $I$ and the apparatus was purged with argon. Then $150 \mathrm{~mL}$ of freshly distilled ether (LAH) was added. To this slurry was then added $40 \mathrm{~mL}$ (80 mmoles) of benzylmagnesium chloride in THF (Aldrich). A clear light brown solution resulted. This mixture was stirred for $15 \mathrm{~h}$ at R.T. after which a milky white solution resulted. This was transferred to a separatory funnel containing $200 \mathrm{~mL}$ of water. The organic phase was then separated, dried (brine and then $\mathrm{Na}_{2} \mathrm{SO}_{4}$ ) and filtered. The colorless solution was then rotary evaporated until a pale yellow oil was obtained weighing $33 \mathrm{~g}$. This oil was extracted with hot hexanes $(5 \times 150 \mathrm{~mL})$ and the pale yellow and clear solution yielded $32 \mathrm{~g} \mathrm{(97 \% )}$ of white crystals of II (not reported in the literature); (mp 110$\left.111^{\circ} \mathrm{C}\right)$.

Elemental analysis: $\quad$ Cal'd $\mathrm{C}=75.90 \%, \mathrm{H}=7.17 \%$

$\mathrm{C}_{30} \mathrm{H}_{34} \mathrm{O}_{5} \quad$ Found $\mathrm{C}=75.86 \%, \mathrm{H}=7.37 \%$

${ }^{1} \mathrm{H} \mathrm{NMR}\left(\mathrm{CDCl}_{3}\right): 87.5-6.8(\mathrm{~m}, 13 \mathrm{H}), 5.4(\mathrm{~S}, 2 \mathrm{H}), 3.9(\mathrm{~m}, 2 \mathrm{H}), 3.6(\mathrm{~s}, 4 \mathrm{H}) 2.3(\mathrm{~s}, 1 \mathrm{H})$, 2.1-1.4 (m, 12 H).

Formation of 1,1-bis(4-hydroxyphenyl)-2 Phenylethylene (BHPE) III

In a $250 \mathrm{~mL}$ r.b.f. equipped with a magnetic follower was placed $10 \mathrm{~g}(22$ mmoles) of $I 1$ and $100 \mathrm{~mL}$ of methanol. To this slurry was then added $5 \mathrm{~mL}$ of conc. $\mathrm{HCl}$. After stirring for $1 \mathrm{~h}$ at ambient temperature, TLC of the reaction mixture vs. II showed 1 spot with a smaller $R_{f}$ value (silicagel, 2:1 hexanes: ethylacetate). This was neutralized with $\mathrm{CO}_{3} \mathrm{Na}_{2}$ and extracted with $\mathrm{CH}_{2} \mathrm{Cl}_{2}$, dried $\left(\mathrm{Mg} \mathrm{SO}_{4}\right)$ and filtered. Rotary evaporation of this solution gave a light orange oil weighing $6 \mathrm{~g}$ (95\% yield). A portion of this oil was crystalized from toluene, $\mathrm{mp} 181-4^{\circ} \mathrm{C}$ (Lit (2) $188^{\circ} \mathrm{C}$ ). 
Synthesis of 1,1 bis[4-hydroxyphenyl)-2-bromo-2-phenylethylene (BrBHPE) IV

The above compound was prepared according to the procedure of Meese and DeSombre (2) in similar yields.

\section{1,1-bis(4-(2-tetrahydropyranyl)oxy)-2-phenylvinylbromide $V$}

In a $250 \mathrm{~mL}$ r.b.f. was placed a magnetic stirrer and $8 \mathrm{~g}$ ( 21 mmoles) of IV and 1 $g$ (4 mmoles) of PPTS. The flask was then surmounted with a reflux condensor and a gas inlet adaptor. The flask was then purged with argon and then $100 \mathrm{~mL}$ of freshly distilled THF (from $L A H$ ) was added. The mixture was made into a solution via stirring and then $6 \mathrm{~mL}$ ( 66 mmoles) of distilled dihydropyran was added via syringe and under argon. The mixture was stirred at R.T. for $10 \mathrm{~h}$ and then refluxed for $2 \mathrm{~h}$. After cooling down to R.T., the TLC of the reaction mixture vs. the starting material showed a spot with greater $R_{f}$ value than $V$. The reaction mixture was then shaken with $100 \mathrm{~mL}$ of brine in a separatory funnel and the organic phase was separated, dried ( $\mathrm{Na}_{2} \mathrm{SO}_{4}$ ), and then filtered. Rotary evaporation gave an orange colored solid which was crystalized from methanol yielding $7 \mathrm{~g}$ (62\% yield) of pale yellow crystals, $\mathrm{mp} 142-3^{\circ} \mathrm{C}$ (Lit.( $7142-5^{\circ} \mathrm{C}$ ).

1H NMR (CDCl 3$): 8$ 7.5-6.6 (m, 13), $5.4(\mathrm{~s}, 1), 5.3(\mathrm{~s}, 1), 4.0-3.7(\mathrm{~m}, 4), 2.1-1.4(\mathrm{~m}, 12)$.

Elemental Analysis: Calc'd. $\mathrm{C}=67.29 \%, \mathrm{H}=5.79 \%$

$\mathrm{C}_{30} \mathrm{H}_{31} \mathrm{BrO}_{4}$ Found $\mathrm{C}=66.72 \%, \mathrm{H}=5.84 \%$

\section{1,1-bis(4-(2-tetrahydropyranyl)oxy)-2-phenylvinyllithium VI}

In a typical reaction $2 \mathrm{~g}$ ( 3.7 mmoles) of $V$ was placed in a Schlenk flask and purged with argon. Then $40 \mathrm{~mL}$ of freshly distilled diethylether (LAH) was added. This led to a slurry which was chilled to $-78^{\circ} \mathrm{C}$ using dry ice/acetone bath. Then 4 mmoles of $n$-butyllithium in hexanes (Aldrich) were added. Following the addition of the lithium 
reagent, the cold bath was removed and the reaction mixture was allowed to reach ambient temperature during a $2 \mathrm{~h}$ period. This led to a clear light orange solution of VI.

\section{Formation of the vinyltributyltin derivative VII}

To this solution (VI) was then added 5 mmoles of tributyltinchloride (Aldrich) and allowed to stir at room temperature for $16 \mathrm{~h}$. A milky white solution signaled the completion of the reaction. TLC of the reaction solution revealed one spot which had distinctly different $R_{f}$ value from that of $V$ on a side by side run. The product VII was purified by passing it through a silicagel column using $4: 1 /$ hexanes: ethyl acetate as the mobile phase. Pure VII is obtained in the form of a colorless oil which shows instability at R.T. as is indicated by new spots on periodic TLC checks.

\section{Deprotection of vinyltributyltin compound and formatin of VIII}

A $1 \mathrm{~g}$ sample of VII was dissolved in $40 \mathrm{~mL}$ of $\mathrm{CH}_{2} \mathrm{Cl}_{2}$. To this solution was added a crystal of PPTS and allowed to stir at R.T. The progress of the reaction was monitored periodically via TLC (silicagel, $2: 1 /$ hexanes : ethylacetate). When BHPE started to show up on TLC the reaction mixture was quenched by adding dilute sodiumbicarbonate solution. After shaking well in a separatory funnel the organic phase was separated and dried $\left(\mathrm{Na}_{2} \mathrm{SO}_{4}\right)$, filtered and rotary evaporated. The residual oil was then purified via column chromatography (silicagel, $4: 1 /$ hexanes: ethylacetate) and stored at $-80^{\circ} \mathrm{C}$.

\section{Formation of 1,1-bis(4-hydroxyphenyl)-2-phenyl-2-iodoethylene (1-BHPE) IX}

$1 \mathrm{~g} \mathrm{(4} \mathrm{mmoles)} \mathrm{of} \mathrm{iodine} \mathrm{(Aldrich)} \mathrm{was} \mathrm{placed} \mathrm{in} \mathrm{a} \mathrm{Schlenk} \mathrm{flask} \mathrm{and} \mathrm{purged}$ with argon gas. To this was then added $25 \mathrm{~mL}$ of dry ether and mixed until the iodine was dissolved. A solution of VI prepared from $1 \mathrm{~g}$ ( 2 mmoles) of $V$ as described above. The iodine solution was then added dropwise to the vinyl lithium solution via syringe 
until the red color of iodine persisted. The solution was then worked up by treating it with $50 \mathrm{~mL}$ of a saturated solution of sodiumthiosulfate (in order to reduce the excess

iodine), dried $\left(\mathrm{MgSO}_{4}\right)$ and then filtered. Rotary evaporation yielded an orange colored oil (one spot on TLC, 2:1 / hexanes : ethylacetate, $R_{f}$ identical to $V$ ). This oil was consequently dissolved in $50 \mathrm{~mL}$ of methylene chloride and a crystal of PPTS was added. The progress of the reaction was monitored via TLC (silicagel, 2:1 / hexanes : ethylacetate, $R_{f}$ identical to IV). After the reaction was completed the product was purified by passing it through a silicagel column. Crystallization from toluene yielded $0.5 \mathrm{~g}\left(60 \%\right.$ yield) of reddish brown crystals ( $\mathrm{mp} 177-80^{\circ} \mathrm{C}$, Lit. (7) $\left.175^{\circ} \mathrm{C}\right)$.

1H NMR ( $\left.\mathrm{CDCl}_{3}\right): 87.5-7,6.95-6.6,6.5-6.3(\mathrm{~m}, 14), 5.5-4(\mathrm{~m}, 2), 2.4(\mathrm{~s}, 1)$

MS : $414\left(M^{+}\right.$peak), 100\%; $287\left(M^{+-}\right), 96 \%$

Elemental Analysis:

Calc'd. $\mathrm{C}=55.50 \%, \mathrm{H}=3.93 \%, \mathrm{l}=29.40 \%$

$\mathrm{C}_{20} \mathrm{H}_{17} \mathrm{I} \mathrm{O}_{3}\left(\mathrm{I}-\mathrm{BHPE} . \mathrm{H}_{2} \mathrm{O}\right) \quad$ Found $\mathrm{C}=55.53 \%, \mathrm{H}=3.94 \%, \mathrm{I}=29.46 \%$

\section{ACKNOWLEDGEMENT}

The technical assistance of Mr. James A. Dawn (visiting student, University of Mary Hardin-Baylor, Belton, Texas) is greatly appreciated. Research was supported by the office of Health and Environmental Research, U.S. Department of Energy and grants from National Cancer Institute (CA 27476 and CA 49906) and Dow Chemical Company. 


\section{LITERATURE CITED}

1) See for example: V.C. Jordan et al (1978) Nonsteroidal Antiestrogens: Their biological effects and potential mechanisms of action J. Toxicol. Envir. Health $4,363$.

2) R.H. Seevers, R.C. Mease, A.M. Friedman and E.R. DeSombre (1986) The Synthesis of non Steroidal Estrogen Receptor Binding Compounds Labeled with $80 \mathrm{~m}_{\mathrm{Br}}$ Nucl. Med. Biol. 13, No. 4, 483-495.

3) J. Grundy (1957) Artificial estrogens. Chem. Rev. 57, 281-416.

4) W.E. Parham and E.L. Anderson (1948) The Protection of Hydroxyl Groups J. Am. Chem. Soc. 70, 4187-9.

5) a) Wadie Tadros and J.M. Robson (1947) Highly Active Triphenylethylene Derivatives Nature. 160, 20-21.

b) J.F. Miquel et al (1978) Synthese de polyphenylethylnes et interferences avec le recepteur estrogene d'uterus de Souris C.R. Acad. Sc. Paris, t. 286, Serie $C ; 151-4$.

c) J. Gilbert et al (1983) Inhibition of Prostaglandin Synthetase by Di- and Triphenylethylene derivatives: A structure-Activity Study J. Med. Chem., 26, 693-9.

6) B. Blagoev and D. Ivanov (1970) Syntheses with Polyfunctional Organomagnesium Compounds Synthesis, No. 12, 615-27.

7) E.R. DeSombre, R.C. Meese, Jigi Sanghavi, Tej Singh, R.H. Seevers and Alun Hughes (1988) Estrogen Receptor Binding Affinity and Uterophic Activity of Triphenylethylenes J. Steroid Biochem,No. 6, 583-90. 
Scheme I<smiles>C[C@H]1CC2CCC(CC2)O1</smiles><smiles>O=C(c1ccc(OC2CCCCO2)cc1)c1ccc(OC2CCCCO2)cc1</smiles>

$\longrightarrow \mathrm{CH}_{2} \mathrm{MgCl}+\mathrm{I} \longrightarrow \stackrel{\mathrm{H}_{2} \mathrm{O}}{\longrightarrow}$<smiles>OC(Cc1ccccc1)(c1ccc(OC2CCCCO2)cc1)c1ccc(OC2CCCCO2)cc1</smiles>

II<smiles>C[CH+]C</smiles><smiles>Oc1ccc(C(=Cc2ccccc2)c2ccc(O)cc2)cc1</smiles> 
Scheme II

$\mathrm{III}+2\left(\mathrm{CH}_{3} \mathrm{CO}\right)_{2} \mathrm{O}+2 \mathrm{Et}_{3} \mathrm{~N} \longrightarrow$<smiles>CC(=O)Oc1ccc(C(=Cc2ccccc2)c2ccc(OC(C)=O)cc2)cc1</smiles>

IV

$\mathrm{IV}+\mathrm{Br}_{2} \longrightarrow \mathrm{CCl}_{4}$<smiles>CC(=O)Oc1ccc(C(=C(Br)c2ccccc2)c2ccc(OC(C)=O)cc2)cc1</smiles>

IVa $\stackrel{\mathrm{OH}^{-}}{\longrightarrow} \stackrel{\mathrm{H}^{+}}{\longrightarrow}$<smiles>Oc1ccc(C(=C(Br)c2ccccc2)c2ccc(O)cc2)cc1</smiles>

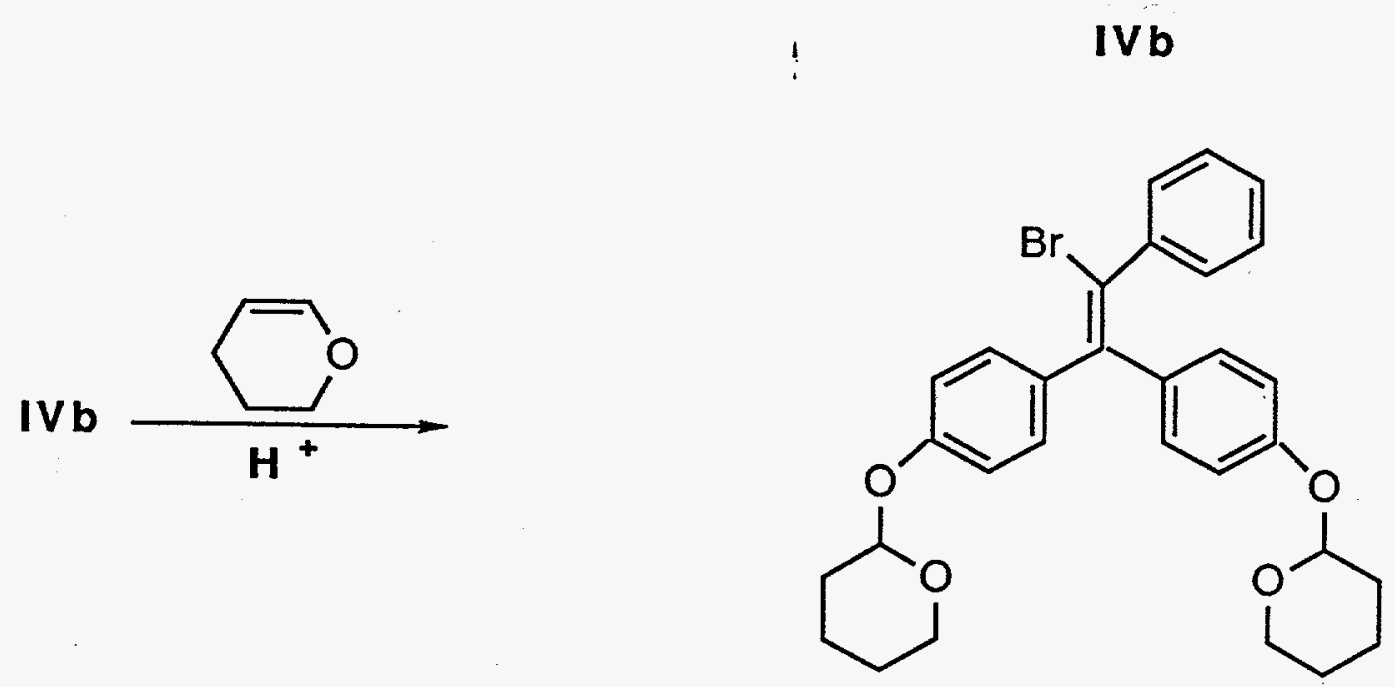


Scheme III

$$
v+n-B u L i \stackrel{\text { Ether }}{\longrightarrow}
$$<smiles>[Tl]C(=C(c1ccc(OC2CCCCO2)cc1)c1ccc(OC2CCCCO2)cc1)c1ccccc1</smiles>

$$
\mathrm{VI}+(\mathrm{Bu}) 3 \mathrm{Sn}-\mathrm{Cl} \longrightarrow
$$

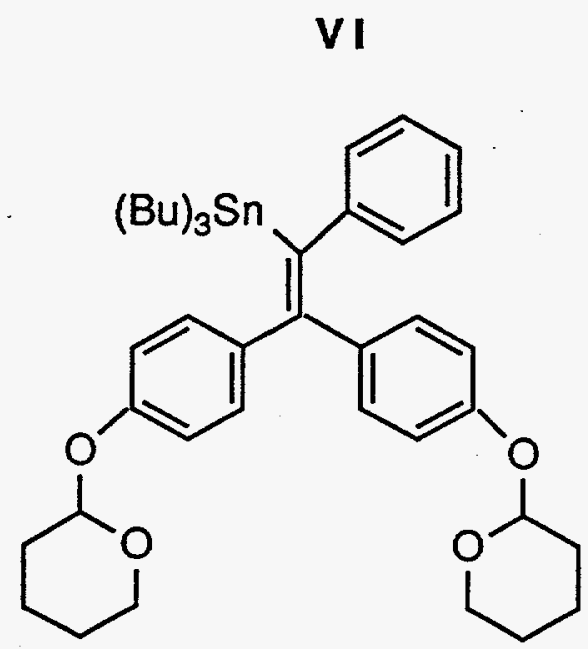

VII

VII + PPTS $\longrightarrow$

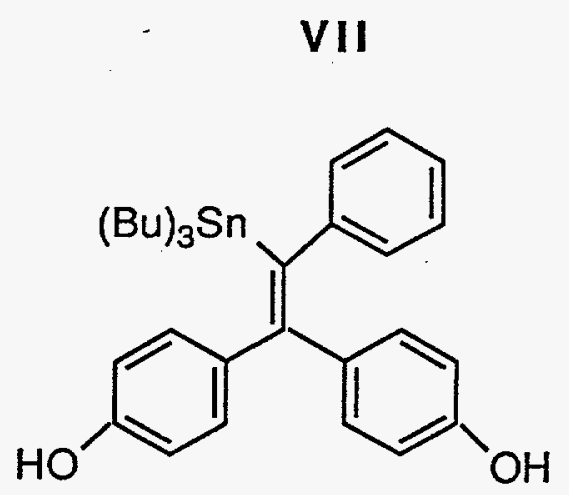

VIII
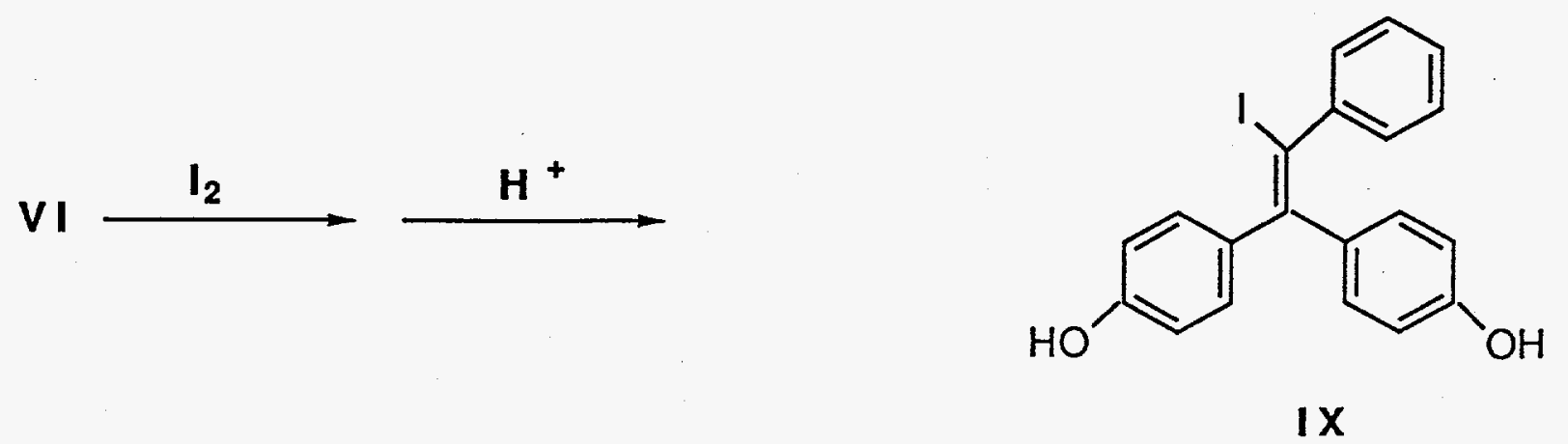